\title{
Technology Provider
}

National Cancer Institute

\section{Source}

National Cancer Institute. Technology Provider. NCI Thesaurus. Code C142729.

An individual or organization that sells software applications or computer hardware. 